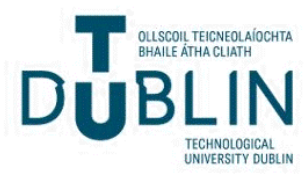

Technological University Dublin

ARROW@TU Dublin

2019-3

\section{Moving Towards the Second Generation of Lignocellulosic Biorefineries in the EU: Drivers, Challenges, and Opportunities}

\author{
Shady S. Hassan \\ Technological University Dublin, shady.hassan@mydit.ie \\ Gwilym A. Williams \\ Technological University Dublin, gwilym.williams@tudublin.ie \\ Amit K. Jaiswal \\ Technological University Dublin, amit.jaiswal@tudublin.ie
}

Follow this and additional works at: https://arrow.tudublin.ie/schfsehart

\section{Recommended Citation}

Shady S. Hassan, Gwilym A. Williams, and Amit K. Jaiswal (2019). Moving towards the second generation of lignocellulosic biorefineries in the EU: drivers, challenges, and opportunities. Renewable and Sustainable Energy Reviews,101, 590-599, 2019.

This Article is brought to you for free and open access by the School of Food Science and Environmental Health at ARROW@TU Dublin. It has been accepted for inclusion in Articles by an authorized administrator of ARROW@TU Dublin. For more information, please contact arrow.admin@tudublin.ie, aisling.coyne@tudublin.ie, gerard.connolly@tudublin.ie.

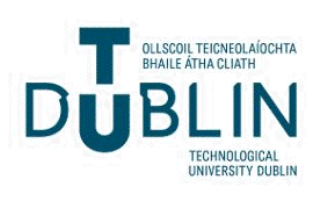




\title{
Moving towards the second generation of lignocellulosic biorefineries in the EU: Drivers, challenges, and opportunities
}

\author{
Shady S. Hassan ${ }^{\mathrm{a}, \mathrm{b}}$, Gwilym A. Williams ${ }^{\mathrm{b}}$, Amit K. Jaiswal ${ }^{\mathrm{a}, *}$ \\ ${ }^{a}$ School of Food Science and Environmental Health, College of Sciences and Health, Dublin Institute of Technology, Cathal Brugha Street, Dublin 1, Ireland \\ ${ }^{\mathrm{b}}$ School of Biological Sciences, College of Sciences and Health, Dublin Institute of Technology, Kevin Street, Dublin 8, Ireland
}

\section{A R T I C L E IN F O}

\section{Acronyms:}

ECthe European commission

UNthe United Nations

FAOthe Food and Agriculture Organization

WHOthe World Health Organization

GHGgreenhouse gas emissions

SDGthe sustainable development goals

SRWCshort rotation woody crops

IBLCintegrated biomass logistics center

Keywords:

Lignocellulose

Biorefinery

Bioenergy

Biofuel

Biochemicals

Biomaterials

\begin{abstract}
A B S T R A C T
The EU aims to achieve a variety of ambitious climate change mitigation and sustainable development goals by 2030. To deliver on this aim, the European Commission (EC) launched the bioeconomy strategy in 2012. At the heart of this policy is the concept of the sustainable Biorefinery, which is based centrally on a cost-effective conversion of lignocellulosic biomass into bioenergy and bioproducts. The first generation of biorefineries was based on utilization of edible food crops, which raised a "food vs. fuel" debate and questionable sustainability issues. To overcome this, lignocellulosic feedstock options currently being pursued range from non-food crops to agroforestry residues and wastes. Notwithstanding this, advanced biorefining is still an emerging sector, with unanswered questions relating to the choice of feedstocks, cost-effective lignocellulosic pretreatment, and identification of viable end products that will lead to sustainable development of this industry. Therefore, this review aims to provide a critical update on the possible future directions of this sector, with an emphasis on its role in the future European bioeconomy, against a background of global developments.
\end{abstract}

\section{Introduction}

Unprecedented challenges now face the future development of Europe, spanning food security, climate change, and an over-dependence on non-renewable resources. Simultaneously, it must balance strategies that harness renewable resources to maintain environmental sustainability, while maintaining economic growth. To achieve this, in 2012, the European Commission (EC) launched the European bioeconomy strategy entitled "Innovating for sustainable growth: a bioeconomy for Europe". The interim fruits of this initiative were assessed by the EU Commission in 2017 and indicated that the scope of the current action plan was insufficient for the development needs of the biorefinery sector. Within this strategy, the modern bioeconomy is defined centrally by the production of biomass or the utilization of lignocelluosic wastes, with subsequent conversion into value-added products, such as bio-energy, as well as novel bio-based innovation. At the EU level, the cur- rent bioeconomy has an annual turnover of 2.3 trillion EURO, and generates a total employment of 18.5 million people.

Biorefining is defined as the sustainable processing of biomass into a spectrum of marketable products (food, feed, chemicals, and materials) and energy (fuels, power and/or heat) [1]. Representing a cornerstone of the bioeconomy, the goal of fully unlocking the value potential of lignocellulosic plant biomass in a cost-effective way remains elusive. A 'one-size-fits-all' biorefinery concept, based on conversion of various lignocellulosic biomass feedstocks into bioenergy and bioproducts, has not yet been achieved. Upstream aspects such as biomass type, transport logistics and the downstream value proposition offered by conversion products must be reconciled with the recalcitrance of the lignocellulosic structure: there is, as yet, no fully scalable yet cost-effective extraction method to unlock valuable sugars and lignin from this matrix, and this remains a key short-term research goal.

Lignocellulosic feedstock options for biorefinery use range from food/non-food crops to primary residues/secondary wastes from agroforestry. The S2Biom project has estimated that a total of 476 million

\footnotetext{
* Corresponding author.

Email address: amit.jaiswal@dit.ie, akjaiswal@outlook.com (A.K. Jaiswal)
} 
tons of lignocellulosic biomass need to be secured to fulfil demand for bio-based products by 2030 [2]. The market for bio-based products is expected to be worth 40 million EURO by 2020, increasing to about 50 billion EURO by 2030 (average annual growth rate of 4\%). Research in industry and academia has been galvanized to address the twin challenge of lignocellulosic breakdown and conversion into viable products: between 130-150 patents are annually submitted in the lignocellulosic biofuel area, and this is expected to reach 200 annual filings [3]. Additionally, a myriad of publications featuring laboratory and pilot scale studies for pretreatment and conversion of lignocellulosic biomass into bioenergy and bioproducts are published each year. Within the context of biofuel production, 67 lignocellulosic biorefineries currently operate around the world (albeit only about one-third operating at commercial scale), while additional advanced biorefineries are under development [4]. Hence, this article aims to outline a possible roadmap of the future biorefining industry in Europe by reconciling market drivers with current technical challenges, and future opportunities; in addition to research and innovation in this area.

\section{The drivers for the development of biorefinery industry in the EU}

\subsection{Global environmental concerns}

Assuming that the current population growth rate of approximately 83 million people continues each year, about 8.5 billion people will share the Earth by 2030 [5]. Thus, demands for food, energy and economic development will continue to increase. The total energy consumption in the world is expected to increase by $48 \%$ between 2012 to 2040, with estimates of 664 and 860 quadrillion kilojoules (KJ) in 2020 and 2040, respectively [6]. Moreover, the Food and Agriculture Organization (FAO) has projected an annual growth rate of total world consumption of all agricultural products to be 1.1 percent per year from 2005-2050; this translates into a requirement for a $60 \%$ higher global production in 2050 than that of 2005 [7]. Such increases in productivity must be achieved against a background of diverse pressures on natural resources, such as land availability, water shortages and unpredictable climate change impacts. The FAO has estimated that an additional 70 million ha of cultivated land may be required by 2050, which will need significant investment. However, the challenge is further exacerbated by the fact that most of the projected lands for expansion in cultivation are in developing countries in Africa, which are often characterized by water scarcity. Moreover, there is increasing competition for land use between urbanization and agriculture. It has been reported that $1.8-2.4 \%$ of global cultivated land loss (equal to $3-4 \%$ of worldwide crop production in 2000) may occur by 2030 due to urban expansion, particularly in Africa [8]. Additionally, nature is suffering a further onslaught in the form of climate change, worsened by increased population growth and associated economic activities: increased global greenhouse gas emissions (GHG), environmental pollution, the ever-increasing volume of solid wastes and over-exploitation of natural resources are all key challenges that need to be tackled. Total GHG were measured at approximately 51.9 gigatonnes of equivalent carbon dioxide $\left(\mathrm{GtCO}_{2} \mathrm{e}\right)$ per year in 2016 , while the ambitious global target is to reduce the GHG to $11-13.5$ GtCO2e by 2030 [9]. The World Health Organization (WHO) reported that 3 million people are killed annually by outdoor air pollution, and that only one-person-in-ten lives in a city that complies with the WHO air quality standards [10]. The World Bank has estimated that cities around the world generate about 1.3 billion tonnes of solid waste per year, costing \$205.4 billion in waste management, and this volume is expected to increase to 2.2 billion tonnes by 2025 , with concomitant increases in waste management costs to $\$ 375.5$ billion [11]. Around the world, over $80 \%$ of all wastewater is discharged into water bodies each year without treatment
[12]. In addition, the unsustainable use of natural resources by excessive fishing, hunting and forestry represents an alarming threat to global biodiversity. Global wildlife populations have declined on average by $58 \%$ since 1970 , and this may reduce further to $67 \%$ by 2020 [13]. To overcome these unprecedented environmental challenges, in 2015, the 193-member states of the United Nations came to an agreement on 17 sustainable development goals (SDG) for 2030 [14]. The SDG included ensuring sustainable consumption and production patterns, promotion of socially responsible industrialization and fostering of an innovation culture, ensuring access to affordable and clean energy for all, and taking urgent action to combat climate change. Additionally, the UN countries adopted the international climate mitigation agreement in 2015 at the Paris climate conference which aims to limit global warming to below $2{ }^{\circ} \mathrm{C}$ on a national level. In this context, fostering the global bioeconomy ethos as the pathway for achieving SDGs and climate change mitigation is vital.

\subsection{The EU environmental challenges and the future bio-based economy}

Viewed through the lens of environmental sustainability, many of the global concerns are also relevant to the situation of the EU, and span over-dependence on fossil fuels, intensive agriculture, over-fishing, non-sustainable forest and water resources management, pollution, and poor land use. The EU possesses a high ecological footprint of 4.7 global hectares per person, which is equal to twice the size of its biocapacity [15]. Worryingly, environmental concerns in other regions of the world also affect the EU directly, through the impact of global GHG, or via socio-economic pressures emanating from the global loss of biodiversity or over-exploitation of natural resources. Driven by such challenges, the EU launched the bioeconomy strategy in 2012 and established tangible action plans to actively shape the targeted circular economy in Europe by 2030, thus enabling it to assume leadership in this field. As a direct consequence, the industrial revolution in the 21 st century is likely to be based on renewable biological resources, with a paradigm shift in evidence after the historical reliance on oil and other fossil fuels which came to dominance over the past three hundred years. In this context, biorefining represents a bridge to a sustainable bio-based industry by conversion of biomass into valuable products. However, when compared to fossil-based refineries, biorefineries are an embryonic industry, with a variety of different biomass feedstocks, a need for efficient conversion technologies and a portfolio of products which may have varying market receptivity.

\section{The challenges in the biorefining value chain}

\subsection{Feedstocks}

Integral to the biorefinery concept is accessing suitable feedstocks which are amenable to cost-effective processing. Biorefining is a capital-intensive industry with large capital expenditure (CAPEX) and requires knowledge of the feedstock resource base that is sustainably available at low cost to support a facility.

\subsubsection{First generation (food crops)}

The first generation of feedstocks depended on easily accessible and edible fractions of food crops, with the main product being biofuel. Bioethanol may be produced from sugar (e.g. sugarcane, sugarbeet, and sweet sorghum) and starch (e.g. corn, and cassava) crops, while biodiesel is produced from oil seed crops (e.g. soybean, oil palm, rapeseed, and sunflower) [16]. However, in recent years, serious criticisms have been raised about competition in land use that has arisen as a direct consequence of incentivizing energy and oil crops at the expense of food crops. 


\subsubsection{Second generation (Non-food crops and lignocellulosic wastes)}

The growing controversy of 'food versus fuel', along with associated production economics, biofuel policies and sustainability trends, promoted the rise of a second generation of feedstocks based on lignocellulosic biomass. The latter include non-food, short rotation grasses that have high yield and suitability to marginal lands or poor soils (e.g. poplar, willow, eucalyptus, alfalfa, and grasses such as switch, reed canary, Napier and Bermuda), agricultural residues (e.g. forest thinning, sawdust, sugarcane bagasse, rice husk, rice bran, corn stover, wheat straw, and wheat bran), and agroindustrial wastes (e.g. potato and , orange peel, spent coffee grounds, apple pomace, ground nut oil and soybean oil cake) [17-19]. Critically, the latter are so-called negative cost waste materials from other industries, and so theoretically the value proposition has heightened appeal. However, such materials are also the most refractory to extraction of sugars (Fig. 1).

3.1.2.1. Non-food terrestrial biomass Non-food energy crops have received much attention as an alternative to food crops during the first phase of transition toward the second generation biorefinery, and these may be categorized mainly into woody and herbaceous crops.

3.1.2.1.1. Woody crops (short rotation woody crops) Examples of short rotation woody crops (SRWC) are cottonwood, silver maple, black locust, willow, poplar, and eucalyptus. Generally, SRWC are hardwood trees that are traditionally used in paper and pulp industries [20]. Wood is an age-old source of energy for man and sustainable systems for its conservation are well established. Furthermore, SRWC has significant advantages over many other lignocellulosic biomass types in terms of widespread availability in most regions of the world, high energy density and existence of well-established handling technologies arising from the pulp and paper industries. However, utilizing the global forests for biorefining as a sole feedstock will have significant effects on forest management, wood processing, and the pulp and paper sectors; such aspects need to be explored fully. Long production cycles (up to 12 years from plantation) are complicated by aspects such as weed control and sustainability of supply. Additionally, the issue of competition with land for other uses (especially food) also remains. The best potential for utilizing woody crops as a biorefinery feedstock lies in integration with wood-based industries, particularly the pulp and paper sectors, as these players currently only extract about $47 \%$ of value from lignocellulosic materials [21].

3.1.2.1.2. Grassy crops (herbaceous perennials) Challenges in exploiting woody crops have led to active investigation of herbaceous perennials as a potential energy crop, as these can grow on marginal lands. These species include herbaceous energy crops such as miscanthus, energy cane and sorghum. Early pioneering work in 1991 by the U.S. Department of Energy in North America focused on Switch grass as a model high energy crop. It was subsequently introduced into Europe and other parts of the world due to its high genetic diversity, good productivity and adaptability [22,23]. In addition, Miscanthus was first introduced from Japan to Europe and then to North America, and has become a leading contender as an energy crop due to its adaptability over a range of European and North American climatic conditions, as reported by the 2012 EU project OPTIMISC (Optimizing Miscanthus Biomass Production) [24]. Energy cane, sorghum, alfalfa, bluestem, and grass varieties such as elephant, wheat, reed canary, Napier and Bermuda are examples of other herbaceous plants which are being investigated as energy crops. Grassy crops have a number of advantages over food crops as an energy feedstock. They are perennial (no need for annual plantation), possess a high harvest index (all parts of plant are used), demonstrate reasonable productivity, and have relatively low water requirements and nutrient inputs. On the down-side, likely future competition with food crops for land use (and indirect land use change), combined with production issues (e.g. weed control) and required production inputs (e.g. nitrogen fertilizers) are all aspects that must be considered.

3.1.2.2. Agroforestry residues and processing wastes Separation of plant biomass intended for the biorefinery from that which may be used in the food/feed-chain is a key aspect of future sustainability. Hence, lignocellulosic materials from wood processing, pulp and paper industries, agricultural residues and agro-industrial wastes hold the most potential for use as feedstocks; they are also low cost, abundantly available and generally comply with environment sustainability goals. However, the transport and handling logistics of this feedstock type, combined with a dearth of cost-effective lignocellulosic pre-treatment operations, are major drawbacks that are delaying progress in their utilization for this purpose. In response to such issues, the EU has funded the SUCELLOG project as an example of an integrated biomass logistics

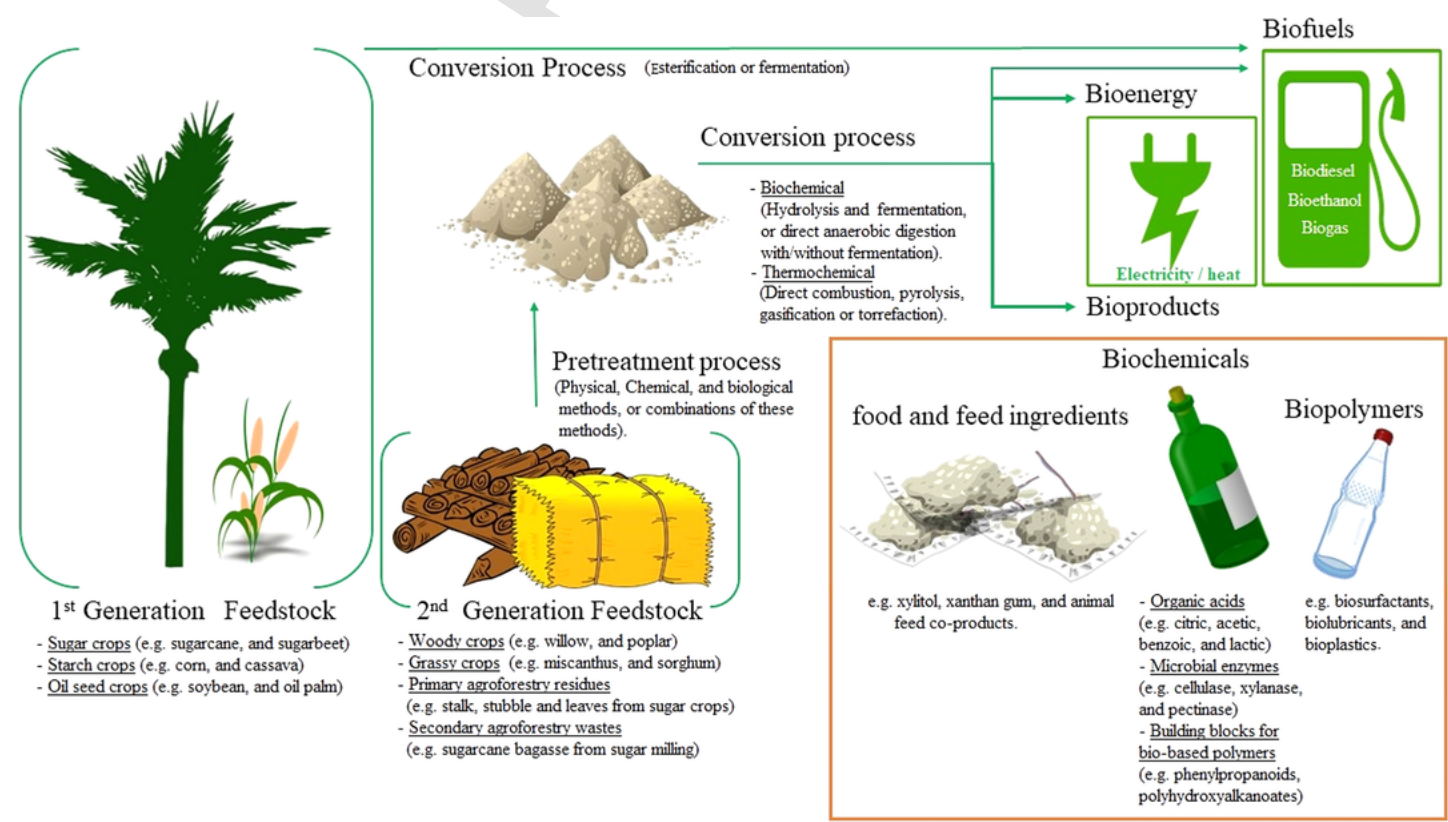

Fig. 1. Schematic diagram shows differences between lignocelluosic feedstocks from the first and second generation: sources, valorisation processes, and end products. 
center (IBLC) in four EU countries (Spain, France, Italy, and Austria). The aim of this work is to overcome aspects such as the seasonable availability of feedstock and supply logistics via improved handling, pretreatment and storage of lignocelluosic biomass in a logistic center, with shipment directly to local biorefineries or transported to be sold to the global market [25]

3.1.2.2.1. Primary agroforestry residues (agricultural \& forestry residues) Agricultural and forestry residues are generated during cultivation activities of crops and trees (e.g. harvesting and shaping) and have a low economic value for primary producers. While both are lignocellulosic in nature, agricultural residues contain a lower level of lignin as compared with forestry residues. It was estimated that the realistic potential of agricultural crop residues is $74.89 \mathrm{Mt} /$ year in the $\mathrm{EU}$, while the realistic potential of forestry residues is $43.5 \mathrm{Mt} / \mathrm{year}$ in the EU, Ukraine and Belarus [26]. The realistic potential is calculated from the technical-sustainable potential, while the latter is derived from the theoretical potential. Examples of agricultural residues are non-edible components of cash crops such as straw (stalks, leaves) from cereals and legumes, as well as stalk, stubble and leaves from sugar, tuber, oil, and vegetable crops. Furthermore, examples of forestry residues are stumps, branches, treetops, needles and leaves after harvesting, weeding, trimming and pruning.

3.1.2.2.2. Secondary agroforestry wastes (food industry \& wood processing wastes) Food industry byproducts encompasses wastes from various industries such as sugarcane bagasse (from sugar milling), pomace (pressing of tomato), apple and grapes (juice), olives (for oil), brewer's spent grain (BSG - from beer-brewing), spent coffee grounds (coffee preparation), as well as citrus and potato peels. The global production of some of these humble wastes are significant. For example, potato peels generate between 70 and 140 thousand tons worldwide every year [27]; this compares with 5-9 million metric tonnes of grape pomace and 3-4.2 million metric tonnes from apple pomace per annum [28]. BSG generated from beer-brewing has been estimated at 3.4 million tonnes annually in the EU alone, and over 4.5 million tons in USA as the largest craft beer producer [29]. Wood processing industries include wastes such as cuttings, shavings, veneer, sawdust and sludge from the production of panels, furniture, cardboard, pulp and paper.

In the $\mathrm{EU}$, around 11 million tonnes of solid waste were generated from paper and pulp industries per annum in 2005 [30]. Significantly, an increase in agricultural residues and wastes is expected to result from a required population-led increase in food production. Following on from this, an increase in forestry residues and wastes is also expected.

\subsubsection{Third generation (non-food marine biomass)}

Algae have been proposed as a potential non-food marine biomass, spanning macroalgae (seaweed) and microalgae. However, the majority of algal species share some of the disadvantages of other second-generation feedstocks: variable efficacy of conversion technologies, and in some cases, high production cost and technical challenges in the scale-up of cultivation operations.

3.1.3.1. Macroalgae (Seaweeds) Seaweeds include green, red and brown macroalgal species such as Ulva lactuca, Gracilaria vermiculophylla and Saccharina latissimi. Classification of seaweeds is based on the composition of their photosynthetic pigments and diverse cellular structures. Seaweeds are currently used in production of food, feed and nutritional supplements. They demonstrate a rapid growth rate, high photosynthetic efficiency and do not require either arable land or fresh water resources to grow [31]. Seaweeds (particularly green algae) have seen noticeable investigation for production of biofuels [32]; the ash content in red and brown algae can reach up to $60 \%$, while the cellulose content is generally low in all seaweeds [33].
3.1.3.2. Microalgae Examples of microalgae include Schiochytrium sp., Botryococcus braunii, Nitzschia, Hantzschia, and Neochloris oleoabundans. Microalgae are generally richer in lipid content compared with carbohydrate, and therefore attention has focused on their use for biodiesel production. However, biodiesel production from microalgae demonstrates a relatively low production capacity and higher production cost compared with the use of lignocellulosic biomass: about $90 \%$ of biodiesel production costs are represented by microalgae production [34].

\subsection{Valorisation of second generation feedstock processes}

Scale-up and industrialization of the first generation of biofuels was achieved smoothly. A key enabling factor in their development was the relative ease of extraction of fermentable sugars and oils from the plant biomass. Processes based on extraction of sucrose from the stem of sugarcane to produce bioethanol, or the transesterification of oils from oil palm, soybean or sunflower to produce biodiesel, could all take advantage of pre-existing large-scale extraction technology. However, lignocellulosic biomass from second generation feedstocks are complex structures which contain variable levels of cellulose, in association with tough substrates such as hemicellulose and lignin, as well as other composites. Lignocellulosic structure has been a major impediment to the development of efficient, flexible and scalable pretreatment/conversion technologies: releasing fermentable sugars from this complex structure represents the major hurdle for full valorisation. Fig. 2 shows various drivers, challenges, and opportunities exists for second generation lignocellulosic biorefineries in the EU. During the last two decades, and particularly the last ten years, there has been a tangible growing interest in biorefining (total 4098 publications), with the majority of studies focusing on the development of cost-effective processing methods for biorefinery operations [35].

\subsubsection{Pretreatment of lignocellulosic biomass}

A disruption of the complex lignin-carbohydrate structure in lignocellulosic material is an essential first step in making carbohydrates more available for fermentative processes [36,37]. A variety of approaches have been investigated over the last few decades, spanning physical (e.g. steam explosion and liquid hot water), chemical (e.g.

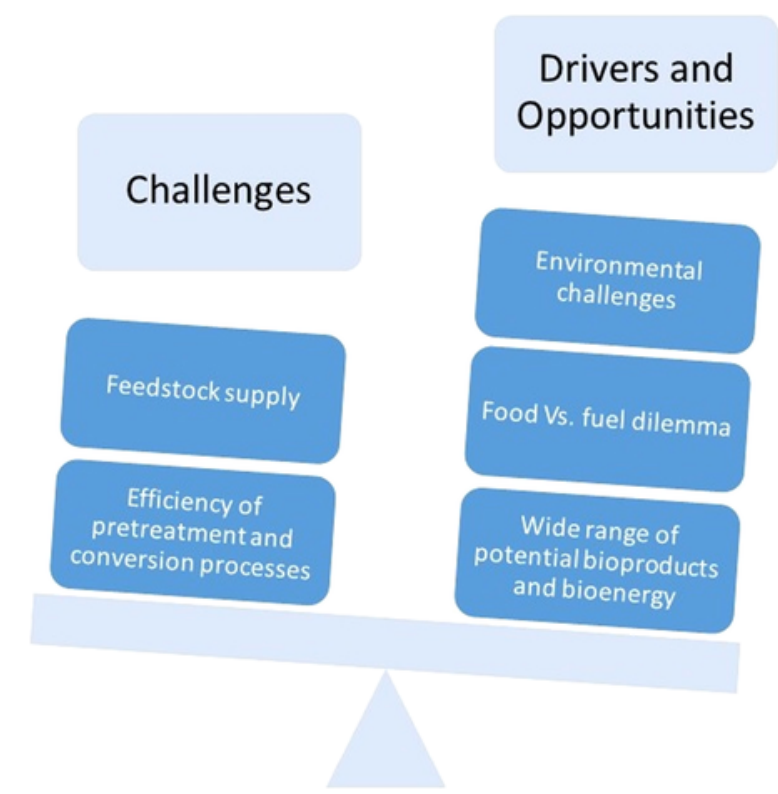

Fig. 2. Drivers, challenges, and opportunities exists for second generation lignocellulosic biorefineries in the EU. 
concentrated acid hydrolysis and dilute acid), biological (e.g. bacteria, fungi), physiochemical (e.g. steam explosion and ammonia fiber expansion) or other combinations of methods (e.g. fungal and physicochemical) [38-42]. However, conventional pretreatments have significant drawbacks. The latter include high energy consumption (cost), environmental concerns and the formation of inhibitors that may limit subsequent fermentation processes [43]. Additionally, the efficiency of thermochemical conversion of lignin may be compromised (e.g. lignin loss or unaltered lignin). Therefore, the development of flexible and scalable technology will be essential for full commercial valorisation of the lignocellulosic biorefinery [44-46].

\subsubsection{Lignocellulose conversion technologies}

Two principal conversion technologies are generally used for valorisation of lignocellulose in the biorefining industry and may be classified as biochemical and thermochemical. Biochemical conversion of lignocellulose involves the hydrolysis of carbohydrates to soluble sugars, followed by microbial fermentation, or by direct anaerobic digestion with/ without fermentation [47], while the thermochemical route involves direct combustion, pyrolysis, gasification or torrefaction [48].

Fermentation is the process of converting sugars to alcohol or acids by microorganisms in the absence of oxygen, while anaerobic digestion is the process by which biomass is broken down by microorganisms in the absence of oxygen to form biogas [49]. In terms of optimizing the biochemical conversion of lignocellulose, the priority mainly lies in development of efficient pretreatment technologies, along with cost-effective hydrolytic enzymes and improved strains of microorganisms [50].

Combustion is a highly exothermic process which features the complete oxidation of biomass, compared with gasification which is the partial oxidation of biomass in the presence of reduced oxidant level. Pyrolysis is the thermo-chemical decomposition of biomass at elevated temperatures (approximately between $500{ }^{\circ} \mathrm{C}$ and $800^{\circ} \mathrm{C}$ ) in the absence of air, and torrefaction is a milder form of pyrolysis conducted at lower temperatures, typically between 200 and $320^{\circ} \mathrm{C}$ [51]. Efficient thermochemical conversion processes will also require improving and standardising the lignocellulose properties of the feedstock by the optimization of lignin content (via plant breeding and environmental stimuli) and heating value levels, and the reduction of minerals, elemental ions, ash and moisture content, as well as the reduction of pollution associated with conversion processes [52].

As a possible solution to these challenges, hybrid approaches based on combined thermochemical-biochemical methods are actively under investigation [53]. However, toxicity of the crude pyrolytic substrates, the formation of growth inhibitors from raw syngas contaminants, and mass-transfer limitations in syngas fermentation are critical challenges which limit the efforts to commercialize hybrid processing. Despite this, combined biochemical and thermochemical conversion technologies represent the greatest hope for exploitation of biomass to produce a broad range of value-added products.

\subsection{The opportunities: Bioenergy and Bioproducts}

Biorefining is analogous to petroleum refineries and have so far been conceptualized around production of energy and biofuels [54]. Furthermore, integrated biorefining to produce a wider range of bio-based products (spanning food, feed, chemicals and biofuels) is the preferred valorisation approach in future bioeconomic models [55]. The global biorefinery products market reached almost US $\$ 438$ billion in 2014, and is expected to reach US $\$ 1128$ billion by 2022 [56]. While over 64 countries and sub-national governments in the world demonstrate strong support for bio-products, and particularly biofuels, the United States and Brazil are the major players in these sectors. The EU also has ambitious national plans in this area (particularly Germany), with an emphasis on biodiesel and biogas. Outside the EU and US, in
Canada, 190 establishments were identified to be engaged in the production or development of industrial bio-products in 2015 (including biofuels, bioenergy, organic chemicals and intermediates, materials and composites). The latter featured estimated total lignocelluosic biomass purchases of $\$ 2.3$ billion: purchases representing 12.3 million metric tonnes of forestry biomass and 8.8 million metric tonnes of agricultural biomass [57].

\subsubsection{Energy}

The current EU policy for renewable energy includes the " $20 / 20 /$ 20" mandatory goals for 2020: a $20 \%$ reduction in $\mathrm{CO}_{2}$ emissions compared to 1990 levels, a $20 \%$ share the energy market for renewables (at least $10 \%$ blending target for transport biofuels) and a $20 \%$ increase in energy efficiency. In energy-driven biorefineries, biomass is utilized for the production of liquid (biodiesel or bioethanol) and/or gaseous (biomethane) road transportation biofuels [58].

3.3.1.1. Liquid biofuel The EU shows an over-reliance on diesel as a transport fuel: the latter is divided into $71 \%$ diesel and $29 \%$ petrol [59]. In fact, $70 \%$ of world sales of diesel cars and vans are represented by Europe [60]. The boom in diesel vehicles that started at the end of the 1990s in the EU was supported by fuel taxation policies and vehicle emission regulations [61]. However, a recent re-evaluation of the polluting capacity of diesel fuel may mean that its EU market share could fall significantly in future years [62]. Contrasting with this, biodiesel engines have a demonstrably lower polluting capacity [63], and are a promising alternative to diesel fuel derived from petroleum sources.

The dominant liquid biofuel in the EU market is biodiesel (81\%), with bioethanol representing $19 \%$ of the market place [59]. However, bioethanol is the dominant biofuel in the global market (80\% market share compared with $20 \%$ for biodiesel; [64]). Table 1 represent the key figures on biofuel production in the United States, Brazil and Europe $[65,66]$.

Biodiesel can be used alone, or it can be blended with petro-diesel to be used in standard diesel engines; it can also be used as a low-carbon alternative to heating oil. It has many advantages over petroleum diesel in having a relatively low environmental impact, and in being biodegradable, while maintaining similar combustion properties to petroleum diesel [67]. A total of 34.08 million tonnes of biodiesel were produced globally in 2016; approximately $37 \%$ of this figure from the EU-28, with a total biodiesel production of 12,610 million tonnes [68]. The key feedstock for production of biodiesel in the EU is rapeseed. However production of biodiesel can also be achieved by esterification of oils and fats from edible oil crops (e.g. palm, sunflower, soybean and rapeseed), non-edible oil crops (e.g. Calophyllum inophyllum, Nicotiana tabacum, Jatropha curcas, Hevea brasiliensis), waste oil (e.g. cooking oil, soapstocks, spent bleaching earth oil), microalgae (e.g. Botryococcus braunii, Phaeodactylum tricornutum, Neochloris oleoabundans), cyanobacteria (e.g. Cyanobacterium aponinum, Phormidium sp., Synechococcus $s p$.), or even yeasts (Rhodotorula sp., Cryptococcus sp. , Lipomyces sp., Candida sp.) [69].

Bioethanol can be used in the production of oxygenated fuel additives (ethanol-petrol blends) to improve petrol fuel properties and to

Table 1

Key figures on biofuel production in the Unites States, Brazil and Europe.

\begin{tabular}{lll}
\hline Country/Region & Bioethanol & Biodiesel \\
\hline & Production (Billion liters) & Production (Billion liters) \\
\hline The United States & $59.8^{\mathrm{a}}$ & $5.5^{\mathrm{b}}$ \\
Brazil & $26.7^{\mathrm{a}}$ & $3.8^{\mathrm{b}}$ \\
Europe & $5.4^{\mathrm{a}}$ & $6.1^{\mathrm{b}}$ \\
\hline
\end{tabular}

"Where:

a Figures of 2017.

b Figures of 2016. 
decrease GHG in gasoline vehicles. More than 119.3 million $\mathrm{m}^{3}$ of bioethanol were produced globally in 2016, while approximately $73 \%$ of the global production came from the United States and Brazil, with a total bioethanol production of 58.5 and 28.4 million $\mathrm{m}^{3}$, respectively [68]. The key feedstock for the global production of bioethanol is maize. However, production of bioethanol can be achieved by fermentation of sugars or starch (after a hydrolysis step) from grain (e.g. maize, wheat) or sugar crops (e.g. sugar cane, sugarbeet) as in the first generation of biofuels, or from saccharification and subsequent fermentation of lignocellulosic feedstock, as in second generation biofuels [70].

3.3.1.2. Biogas Biogas can be used for a diverse range of purposes, including producing heat, steam and electricity, or it can be upgraded to biomethane and used as an equivalent of natural gas as a fuel [71]. In the EU, biogas is mainly used for production of electricity and/or heat. Germany is the leader in biogas production from the fermentation of agricultural crops and residues, accounting for 64 percent of total EU production in 2015. The United Kingdom, along with Estonia, Greece, Ireland, Portugal, and Spain, rely on waste management processes of anaerobic digestion of landfill and sewage sludge for over 80 percent of their biogas [72]. According to the European Biogas Association (EBA), a total of 17,662 biogas plants and 503 biomethane plants were in operation in Europe in 2016 [73]. The EBA further reported that 67\% $(+7,699$ units) of the total increase in biogas plants in the EU from 2009 to 2016 (from 6,227 to 17,662 units) was due to an increase of biogas plants utilizing agricultural substrates. Moreover, in France for example, $48.5 \%$ of the biomethane production in 2016 (199 GWh production share from the total annual production of $410 \mathrm{GWh}$ ) was from facilities that utilize agricultural biomass.

Although the energy-driven model remains dominant in the biorefinery industry, there is a lack of energy balance studies in the published literature to justify the commercial feasibility of available technologies for biorefining of lignocellulose. Table 2 represents examples of literature data on the energy balances of lignocelluosic biorefinery scenarios.

\subsubsection{Bioproducts}

There are only a limited number of product-driven biorefineries in commercial operation today in the EU [74]. However, according to a 2016 survey conducted by the European Commission's Joint Research Centre on EU bio-based industry, 284 products have been developed in total by 50 companies which are either currently or expected to be produced as bio-based products [75].

3.3.2.1. Bio-based food and feed ingredients Food and feed ingredients that can be produced by biorefining of lignocellulose include xylitol (used as sweeter in chewing gum manufacture; [76]), xanthan gum (used as a thickening and stabilizing agent in both food and medicine; [77]) and animal feed co-products generated from biorefining of lignocellulose [74].

Table 2

Literature data on energy balance of lignocelluosic biorefinery (Ethanol production).

\begin{tabular}{cllll}
\hline Biomass & $\begin{array}{l}\text { Corn } \\
\text { stover } \\
{[87]}\end{array}$ & $\begin{array}{l}\text { Switchgrass } \\
{[88]}\end{array}$ & $\begin{array}{l}\text { Woody energy } \\
\text { crops [88] }\end{array}$ & $\begin{array}{l}\text { Forest harvest } \\
\text { residues [88] }\end{array}$ \\
\hline $\begin{array}{c}\text { Biomass } \\
\text { yield } \\
\text { Energy } \\
\text { inputs } \\
\text { Net } \\
\text { energy }\end{array}$ & 5212 & 8360 & 10,000 & 8000 \\
\hline
\end{tabular}

*Where Biomass Yield unit is $\mathrm{kg} / \mathrm{ha} / \mathrm{year}$, and Energy unit is MJ/kg biomass.
3.3.2.2. Biochemicals The Bio-based consortium in the EU aims to replace $30 \%$ of overall chemical production with biomass-derived biochemicals by 2030 [78]. According to the National Renewable Energy Laboratory in USA, the latter can be finished products or intermediates that then become a feedstock for further processing [79]. Biochemicals produced from the biorefining of lignocellulose include organic acids (e.g. citric, acetic, benzoic, lactic and succinic), microbial enzymes (e.g. amylase, cellulase, pectinase, xylanase, mannanase), and building blocks for bio-based polymers (e.g. phenylpropanoids, polyhydroxyalkanoates) [80-82]. The projected production of some lignocellulosic-based chemicals and materials in Europe (in 2020 and 2030) is summarized in Fig. 3 [83].

3.3.2.3. Bio-polymers Novel materials that can be produced from biorefining include biosurfactants, biolubricants, and bioplastics (from bio-based polymers e.g. polyesters, polyamides, and polyimides) $[74,80]$. Global output of bio-based polymer production is forecast to increase from 6.6 million tonnes in 2016 to 8.5 million tonnes in 2021, with Europe's share projected to grow from $27.1 \%$ to $26.0 \%$ [84]. Of special note, bioplastics are receiving significant global attention as a replacement for non-degradable plastics that are currently produced in large quantities. On a world-wide basis, 335 million tonnes of plastic materials were produced in 2016 , with $17.9 \%$ of this being produced in the EU [85]. However, Europe's position in producing bio-based polymers is somewhat limited, due mainly to the current preference for starch blends, arising from an unfavorable political framework and a tendency to import biopolymers (e.g. Polybutylene adipate-co-terephthalate and Polylactic acid from Asia; [86]).

\section{Research impact and development trends}

The EU movement towards a "knowledgeable-based economy", that prioritized research and innovation, started in earnest in 2000 when the Lisbon Strategy set out the development action plan for the EU for the first decade of the new century. The Horizon 2020 framework is the current Pan-European research funding programme that will last until 2020, having started in 2014. Under this scheme, seven grand challenges have been identified by the EU where targeted investment in research and innovation may bring the largest impact on society. In this context, Horizon 2020 aims to support European industry through stimulating heightened research and innovation activities. Of special note is the signaling of the importance of biorefining as a pivotal element of the engine of the new bioeconomy. Such innovation represents an important part of the solution for societal challenges relating to food Security and sustainable agriculture, marine, and inland water research, Energy security-efficiency, climate change and integrated transport solution.

The EU established the Bio-based Industries Joint Undertaking (BBI $\mathrm{JU}$ ) in 2014 (due to run until 2024) as a $€ 3.7$ billion Public-Private Partnership between the EU and the Bio-based Industries Consortium.

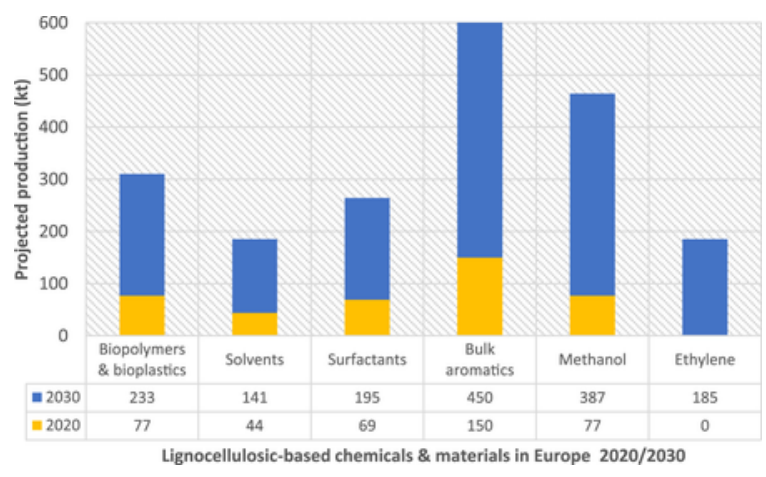

Fig. 3. Projected production of biobased chemicals and materials in Europe 2020/2030. 
The BBI JU aims to develop new biorefining technologies to sustainably convert renewable biomass into biofuels, bioproducts, and biomaterials. Over the first two years, the BBI JU funded 65 projects (with a total investment of 414.29 EUR million) to support the biorefining sector [89]. The majority of BBI JU funding (Fig. 4) is directed at developing lignocellulose-based biorefineries. Examples of current EU-funded projects in lignocellulose biorefining are shown in Table 3 [90]. The ongoing development trends to support biorefining in the EU is focused on three pillars: policies, biomass availability, and value chain modelling (feedstock logistics, processing, and marketing of value-added products) [91].

\subsection{Policies}

The biorefining industry and research within this field has benefited greatly by many EU policy initiatives. The latter include the European bioeconomy strategy for 2020 and beyond (2012), the climate and energy framework for 2030 (2014), and recently the circular economy package for 2030 (2018) [92]. Through such measures, bioeconomy action plans have been developed for sectors such as environment, forestry, agriculture, industry, and energy [93]. However, arguably most of the current policies tend to focus on the bioeconomy in rather general terms. Terms such as 'bioeconomy' and 'bio-based economy' are not equivalent. The term "bioeconomy" is usually associated with conversion processes while "biobased economy" is usually employed in the context of a raw material focus (an instead of non-renewables, such as fossil-based raw material, which here represent the total economy) [94].

Recently, the FAO assessed the classification of sectors such as biorefineries as a pillar of bioeconomic strategy in different countries and regions, including the EU [95]. Results showed that countries such as USA, Australia, Malaysia, and South Africa are actively cultivating biorefining as a component of their bioeconomic strategies. However, while supporting the biofuel-bioenergy sectors, the EU (with the noted exception of Germany) is not taking such an inclusive approach to biorefining.

Over-exploitation of natural resources and food insecurity are among the potential risks from unsustainable practices in primary production [96], and may be partly addressed by novel biorefining approaches. Recently, the commission expert group on bio-based products in the EU reported that progress in the development of a renewables-based economy is at risk of being slower than the rest of the world in achieving the targeted shift to a renewables-based economy [97]. As a result, the expert group recommended the revision of the EU bioeconomic strategy and to extend the BBI JU for a second term.

European Commission initiatives, such as Projects-for-Policy (P4P), aims to use results from research and innovation projects to shape pol-

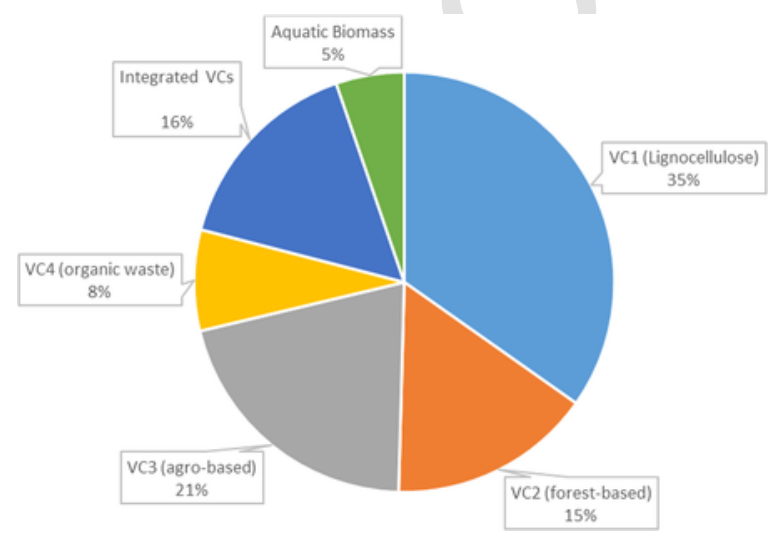

Table 3

The BBI JU funded projects to support lignocellulose biorefining industry in the EU.

\begin{tabular}{|c|c|c|c|c|}
\hline Project/website & $\begin{array}{l}\text { Start } \\
\text { date }\end{array}$ & $\begin{array}{l}\text { End } \\
\text { date }\end{array}$ & $\begin{array}{l}\text { BBI JU } \\
\text { contribution } \\
(€)\end{array}$ & Aim \\
\hline $\begin{array}{l}\text { BIOFOREVER } \\
\text { https://www. } \\
\text { bioforever.org }\end{array}$ & $\begin{array}{l}\text { Sep. } \\
2016\end{array}$ & $\begin{array}{l}\text { Aug. } \\
2019\end{array}$ & $9,937,998.02$ & $\begin{array}{l}\text { Demonstrate the } \\
\text { commercial viability of } \\
\text { lignocellulosic } \\
\text { biorefining (from } \\
\text { woody biomass) for } \\
\text { the chemical industry. }\end{array}$ \\
\hline $\begin{array}{l}\text { BIOSKOH http:// } \\
\text { bioskoh.eu }\end{array}$ & $\begin{array}{l}\text { June } \\
2016\end{array}$ & $\begin{array}{l}\text { May } \\
2021\end{array}$ & 21.568 .195 & $\begin{array}{l}\text { Demonstrate the first } \\
\text { of a series of new } \\
\text { second generation bio- } \\
\text { refineries for Europe. }\end{array}$ \\
\hline $\begin{array}{l}\text { EUCALIVA http:// } \\
\text { eucaliva.eu }\end{array}$ & $\begin{array}{l}\text { Sep. } \\
2017\end{array}$ & $\begin{array}{l}\text { Feb. } \\
2021\end{array}$ & $1,795,009.88$ & $\begin{array}{l}\text { Create a whole value } \\
\text { chain from lignin, } \\
\text { using Eucalyptus waste } \\
\text { as its source. }\end{array}$ \\
\hline $\begin{array}{l}\text { GRACE http:// } \\
\text { www.grace-bbi. } \\
\text { eu }\end{array}$ & $\begin{array}{l}\text { June } \\
2017\end{array}$ & $\begin{array}{l}\text { May } \\
2022\end{array}$ & $12,324,632.86$ & $\begin{array}{l}\text { Explore the potential } \\
\text { of the non-food } \\
\text { industrial crops as a } \\
\text { source of biomass for } \\
\text { the bio-economy. }\end{array}$ \\
\hline $\begin{array}{l}\text { GREENSOLRES } \\
\text { http://www. } \\
\text { greensolres.eu }\end{array}$ & $\begin{array}{l}\text { Sep. } \\
2016\end{array}$ & $\begin{array}{l}\text { Aug. } \\
2021\end{array}$ & $7,451,945.63$ & $\begin{array}{l}\text { Demonstrate the } \\
\text { commercial viability of } \\
\text { converting } \\
\text { lignocellulosic biomass } \\
\text { to levulinic acid. }\end{array}$ \\
\hline $\begin{array}{l}\text { HYPERBIOCOAT } \\
\text { http://www. } \\
\text { hyperbiocoat.eu }\end{array}$ & $\begin{array}{l}\text { Sep. } \\
2016\end{array}$ & $\begin{array}{l}\text { Aug. } \\
2019\end{array}$ & $4,617,423.75$ & $\begin{array}{l}\text { Develop biodegradable } \\
\text { polymers derived from } \\
\text { food processing by- } \\
\text { products. }\end{array}$ \\
\hline IFERMENTER & $\begin{array}{l}\text { May } \\
2018\end{array}$ & $\begin{array}{l}\text { April } \\
2022\end{array}$ & $3,997,825$ & $\begin{array}{l}\text { Conversion of forestry } \\
\text { sugar residual streams } \\
\text { to antimicrobial } \\
\text { proteins by intelligent } \\
\text { fermentation. }\end{array}$ \\
\hline $\begin{array}{l}\text { LIBRE http://www. } \\
\text { libre2020.eu }\end{array}$ & $\begin{array}{l}\text { Nov. } \\
2016\end{array}$ & $\begin{array}{l}\text { Oct. } \\
2020\end{array}$ & $4,566,560$ & $\begin{array}{l}\text { Lignin based carbon } \\
\text { fibres for composites }\end{array}$ \\
\hline $\begin{array}{l}\text { LIGNIOX http:// } \\
\text { www.ligniox.eu/ }\end{array}$ & $\begin{array}{l}\text { May } \\
2017\end{array}$ & $\begin{array}{l}\text { April } \\
2021\end{array}$ & $4,338,374.88$ & $\begin{array}{l}\text { Lignin oxidation } \\
\text { technology for } \\
\text { versatile lignin } \\
\text { dispersants }\end{array}$ \\
\hline $\begin{array}{l}\text { LIGNOFLAG http:// } \\
\text { www.lignoflag- } \\
\text { project.eu }\end{array}$ & $\begin{array}{l}\text { June } \\
2017\end{array}$ & $\begin{array}{l}\text { May } \\
2022\end{array}$ & 24.738 .840 & $\begin{array}{l}\text { bio-ethanol production } \\
\text { involving a bio-based } \\
\text { value chain built on } \\
\text { lignocellulosic } \\
\text { feedstock. }\end{array}$ \\
\hline PEFERENCE & $\begin{array}{l}\text { Sep. } \\
2017\end{array}$ & $\begin{array}{l}\text { Aug. } \\
2022\end{array}$ & $24,999,610.00$ & $\begin{array}{l}\text { Producing FDCA (furan } \\
\text { dicarboxylic acid), a } \\
\text { bio-based building } \\
\text { block to produce high } \\
\text { value products. }\end{array}$ \\
\hline $\begin{array}{l}\text { SSUCHY https:// } \\
\text { www.ssuchy.eu/ }\end{array}$ & $\begin{array}{l}\text { Sep. } \\
2017\end{array}$ & $\begin{array}{l}\text { Aug. } \\
2021\end{array}$ & $4,457,194.75$ & $\begin{array}{l}\text { Sustainable structural } \\
\text { and multifunctional } \\
\text { bio-composites from } \\
\text { hybrid natural fibres } \\
\text { and bio-based } \\
\text { polymers }\end{array}$ \\
\hline SWEETWOODS & $\begin{array}{l}\text { June } \\
2018\end{array}$ & $\begin{array}{l}\text { May } \\
2022\end{array}$ & $20,959,745$ & $\begin{array}{l}\text { Production and } \\
\text { deploying of high } \\
\text { purity lignin and } \\
\text { affordable platform } \\
\text { chemicals through } \\
\text { wood-based sugars }\end{array}$ \\
\hline UNRAVEL & $\begin{array}{l}\text { June } \\
2018\end{array}$ & $\begin{array}{l}\text { May } \\
2022\end{array}$ & $3,603,545$ & $\begin{array}{l}\text { Develop advanced pre- } \\
\text { treatment, separation } \\
\text { and conversion } \\
\text { technologies for } \\
\text { complex lignocellulosic } \\
\text { biomass. }\end{array}$ \\
\hline
\end{tabular}

Fig. 4. BBI JU funding share per value chain (VC) in the EU (2014-2016). 
Table 3 (Continued)

\begin{tabular}{|c|c|c|c|c|}
\hline Project/website & $\begin{array}{l}\text { Start } \\
\text { date }\end{array}$ & $\begin{array}{l}\text { End } \\
\text { date }\end{array}$ & $\begin{array}{l}\text { BBI JU } \\
\text { contribution } \\
(€)\end{array}$ & Aim \\
\hline $\begin{array}{l}\text { US4GREENCHEM } \\
\text { http://www. } \\
\text { us4greenchem. } \\
\text { eu/ }\end{array}$ & $\begin{array}{l}\text { July } \\
2015\end{array}$ & $\begin{array}{l}\text { June } \\
2019\end{array}$ & $3.457 .602,50$ & $\begin{array}{l}\text { Combined Ultrasonic } \\
\text { and Enzyme treatment } \\
\text { of Lignocellulosic } \\
\text { Feedstock as Substrate } \\
\text { for Sugar Based } \\
\text { Biotechnological } \\
\text { Applications }\end{array}$ \\
\hline $\begin{array}{l}\text { VALCHEM http:// } \\
\text { www.valchem.eu }\end{array}$ & $\begin{array}{l}\text { July } \\
2015\end{array}$ & $\begin{array}{l}\text { June } \\
2018\end{array}$ & 13.125 .941 & $\begin{array}{l}\text { Value added chemical } \\
\text { building blocks and } \\
\text { lignin from wood }\end{array}$ \\
\hline WOODZYMES & $\begin{array}{l}\text { June } \\
2018\end{array}$ & $\begin{array}{l}\text { May } \\
2021\end{array}$ & $3,253,874$ & $\begin{array}{l}\text { Extremozymes for } \\
\text { wood based building } \\
\text { blocks: From pulp mill } \\
\text { to board and insulation } \\
\text { products }\end{array}$ \\
\hline $\begin{array}{l}\text { ZELCOR http:// } \\
\text { www.zelcor.eu }\end{array}$ & $\begin{array}{l}\text { Oct. } \\
2016\end{array}$ & $\begin{array}{l}\text { Sep. } \\
2020\end{array}$ & $5,256,993.00$ & $\begin{array}{l}\text { Zero Waste Lingo- } \\
\text { Cellulosic Biorefineries } \\
\text { by Integrated Lignin } \\
\text { Valorisation. }\end{array}$ \\
\hline
\end{tabular}

icy making. In this context, P4P (2018) published reports have recommended policy measures to unlock the unexploited potential of industrial waste streams, and to enhance circular utilisation of resources [98]. Moreover, independent alliances, such as the European Bioeconomy Alliance, have requested revision of the bioeconomy strategy to ensure that biorefineries and related technologies become an integral part of EU level policies [99].

\subsection{Biomass availability}

The supply of lignocellulosic biomass in the EU varies with respect to source, quantity, composition and cost. A number of studies have produced varying data regarding the availability of (sustainable) lignocelluosic biomass in the EU (and beyond) [100]; part of this challenge relates to varying estimates of available land area and agricultural productivity in the future. The perspective is also complicated by additional factors, such as climate change. The project "Biomass Futures" (2010-2012) estimated the future availability of lignocellulosic biomass based on review of previous studies (EUBIONET, RENEW, REFUEL, BEE, Elobio,4FCROPS) and attempted to model the biomass supply chain to provide data for decision makers and other stakeholders [101]. The project identified agricultural wastes as the largest reservoir of cost-effective feedstocks while forestry residues represented the most expensive.

The S2Biom project (2013-2016) investigated the sustainable potential of about fifty feedstock types available across the EU (in addition to Western Balkans, Moldova, Turkey and Ukraine) [2]. However, S2Biom recommended further research work on improving yield, cropping technologies, biomass composition, and competition for resources (e.g. land and water).

The BioTrade2020plus project (2014-2016) studied the potential sustainability of sourcing lignocellulosic biomass (wood chips, pellets, torrefied biomass and pyrolysis oil) from the main geographic regions outside the EU (Canada, US, Russia, Ukraine, Latin America, Asia and Sub-Saharan Africa) [102]. The project raised concerns about the cost efficiency of importing lignocellulosic biomass from forest residues, and considered agricultural residues as "the cheapest option". Furthermore, in the case of strong global climate policy, such regions will probably retain a greater percentage of biomass for domestic use. Therefore, future biomass supply to Europe may be jeopardized.

Recently, the AGRIFORVALOR Project (2018) studied the potential of lignocellulosic biomass residues and wastes for a sustainable biobased economy in the EU [103]. The project estimated the availability and type of lignocellulosic residues and wastes through conducting literature reviews and interviews with farmers, foresters and industry. The project developed three potential investment opportunity scenarios based on Spain (biorefinery of olive biomass), Ireland (biorefinery of grass) and Hungary (biorefinery of whey and straw). The primary focus of most biomass availability studies recently conducted has been on the production of biofuels and bioenergy. More studies are required on cost efficiency of multiproduct biorefining, combined with an examination of greenhouse gas emissions associated with multiproduct biorefining of different biomass feedstock.

\subsection{Biomass value chain modelling}

Feedstock supply, processing and product markets are the main components of the targeted value chain. Regardless of lignocellulosic biomass type, in most cases feedstock is collected at a certain location near the source(s) and then transported (by methods such as road and rail) to biorefineries at different locations. Therefore, managing the feedstock supply chain can effectively reduce the cost of feedstock supply, and therefore the cost of the final product, as well as ensuring sustainable supply of feedstock [104]. However, lignocellulosic biomass varies in nature, and the structure of the supply chain is different, so no standard model can be applied directly for supply of any biomass. Therefore, studies have attempted to optimize the feedstock supply chain, taking into account supply and demand uncertainties [105]. Additionally, value chain models have developed to allow for flexible conversion scenarios [106], and this has encouraged additional study of the impact of conversion technology choice and targeting of final products for value chain optimization.

Lignin and sugar valorisation is a noteworthy focus in such work, as well as the production of biochemical, biopolymers and bioethanol. Such an integrated biorefining model, along with the use of efficient conversion technologies, is expected to provide the best chance for more widespread commercialization of lignocellulosic biorefineries, an aspect which thus far has been difficult to achieve [107-109]. However, given multi-faceted nature and fast-changing character of this sector, predictions for the future of the biorefinery sector will carry a degree of uncertainty [110].

\section{Conclusion}

Driven by global environmental challenges, the EU is attempting to take a large step towards a modern bioeconomy. At the heart of this strategy is a new biorefinery concept based on replacement of first generation feedstocks derived from edible crops with second generation lignocellulosic materials and wastes. Valorisation of technologies is still a formidable hurdle facing the development of this nascent industry, and productive integration of individual biorefinery operations remains at a relatively early stage. Although biorefining aimed at energy production remains the most dominant model in this industry, product-driven biorefining is a promising business with a growing market share. The current ongoing research in the area of biorefineries is therefore focused on developing an advanced model which can utilize a wide range of feedstocks, have integrated conversion processes, and produce a greater variety of higher value end products.

\section{Acknowledgement}

Authors would like to acknowledge the funding from Dublin Institute of Technology (DIT) under the Fiosraigh Scholarship programme, 2017. 


\section{References}

[1] IEA Bioenergy Task 42, Biorefineries: adding value to the sustainable utilisation of biomass, IEA Bioenergy (2009).

[2] S2Biom. Vision for 1 billion tonnes of dry lignocellulosic biomass for the biobased economy in 2030; 2016.

[3] H. Toivanen, M. Novotny, The emergence of patent races in lignocellulosic biofuels, 2002-2015, Renew Sustain Energy Rev (2017) 318-326-77, https://doi.org/ 10.1016/j.rser.2017.03.089.

[4] Q. Nguyen, J. Bowyer, Global production of second generation biofuels: trends and influences, Dovetail Partners (2017).

[5] Dugarova E, Gülasan N. Global trends - challenges and opportunities in the implementation of the sustainable development goals. New York; 2017.

[6] International Energy Outlook 2016. U.S. Energy Information Administration; 2016.

[7] Alexandratos N, Bruinsma J. World agriculture towards 2030/2050: the 2012 revision. Rome; 2012

[8] C. Bren, F. Reitsma, G. Baiocchi, S. Barthel, B. Güneralp, K.-H. Erb, et al., Future urban land expansion and implications for global croplands, PNAS Direct Submiss 114 (2017) 8939-8944, https://doi.org/10.1073/pnas.1606036114.

[9] The Emissions Gap Report 2017. A UN Environment Synthesis Report. Nairobi; 2017.

[10] Ambient air pollution: a global assessment and burden of disease. Geneva; 2016

[11] D. Hoornweg, P. Bhada-Tata, What a waste. A global review of solid waste management, The world bank, 2012

[12] Unesco, Wastewater: the untapped resource, United Nations Educational, Scientific and Cultural Organization, 2017.

[13] WWF. Living Planet Report 2016 Risk and resilience in a new era. Gland; 2016

[14] Sustainable development goals. World Wide Fund for Nature; 2015.

[15] Biodiversity Information system for Europe. Overexploitation. 〈https:// biodiversity.europa.eu/topics/overexploitation〉 [Accessed March 28, 2018].

[16] A. Mohr, S. Raman, Lessons from first generation biofuels and implications for the sustainability appraisal of second generation biofuels, Energy Policy 63 (2013) 114-122, https://doi.org/10.1016/j.enpol.2013.08.033.

[17] S. Amaducci, G. Facciotto, S. Bergante, A. Perego, P. Serra, A. Ferrarini, et al., Biomass production and energy balance of herbaceous and woody crops on marginal soils in the Po Valley, GCB Bioenergy 9 (2017) 31-45, https://doi.org/10. 1111/gcbb.12341.

[18] P.K. Sadh, S. Duhan, J. Singh Duhan, Agro-industrial wastes and their utilization using solid state fermentation: a review Background, Bioresour Bioprocess (2018) 5-10, https://doi.org/10.1186/s40643-017-0187-z.

[19] A.L. Woiciechowski, A. Bianchi, P. Medeiros, C. Rodrigues, L. Porto, D.S. Vandenberghe, Green fuels technology, Springer, 2016https://doi.org/10.1007/ 978-3-319-30205-8

[20] V. Popa, I. Volf, Biomass as renewable raw material for bioproducts of high tech-value, Elsevier Science Ltd, 2018.

[21] V. Chunilall, Chemistry: the key to making more of the pulp and paper industry's waste, CSIR Sci Scope 10 (2017) 30-31.

[22] D.K. Lee, E. Aberle, E.K. Anderson, W. Anderson, B.S. Baldwin, D. Baltensperger, et al., Biomass production of herbaceous energy crops in the United States: field trial results and yield potential maps from the multiyear regional feedstock partnership, GCB Bioenergy (2018) https://doi.org/10.1111/gcbb.12493.

[23] L. Wright, Historical perspective on how and why switchgrass was selected as a "model" high-potential energy crop, U.S. Department of Energy, 2018.

[24] I. Lewandowski, J. Clifton-Brown, L.M. Trindade, G.C. van der Linden, K.-U. Schwarz, K. Müller-Sämann, et al., Progress on optimizing miscanthus biomass production for the european bioeconomy: results of the EU FP7 project OPTIMISC, Front Plant Sci 7 (2016) 1620, https://doi.org/10.3389/fpls.2016.01620.

[25] Annevelink B, van Gogh B, Sebastián Nogués F, Espatolero S, De la Cruz T, Luzzini D, et al. Updated conceptual description of an integrated biomass logistics centre (IBLC); 2016.

[26] Iqbal Y, Lewandowski I, Weinreich A, Wippel B, Pforte B, Hadai O, et al. Maximising the yield of biomass from residues of agricultural crops and biomass from forestry. Berlin; 2016

[27] D. Wu, Recycle technology for potato peel waste processing: a review, Procedia Environ Sci 31 (2016) 103-107, https://doi.org/10.1016/j.proenv.2016.02.014.

[28] L.A. Pfaltzgraff, M. De bruyn, E.C. Cooper, V. Budarin, J.H. Clark, Food waste biomass: a resource for high-value chemicals, Green Chem 15 (2013) 307, https: //doi.org/10.1039/c2gc36978h.

[29] J. Buffington, The economic potential of brewer's spent grain (BSG) as a biomass feedstock, Adv Chem Eng Sci 4 (2014) 308-318, https://doi.org/10.4236/aces. 2014.43034.

[30] Barton A. Novel bio-based products from side streams of paper and board production; 2016

[31] N. Konda, S. Singh, B.A. Simmons, D. Klein-Marcuschamer, An investigation on the economic feasibility of macroalgae as a potential feedstock for biorefineries, Bioenerg Res 8 (2015) 1046-1056, https://doi.org/10.1007/s12155-015-9594-1.

[32] S. Kawai, K. Murata, Biofuel production based on carbohydrates from both brown and red macroalgae: recent developments in key biotechnologies, Int J Mol Sci 17 (2016) 145, https://doi.org/10.3390/ijms17020145.
[33] S. Rocca, A. Agostini, J. Giuntoli, L. Marelli, Biofuels from algae: technology options, energy balance and GHG emissions, JRC Sci Hub (2015) https://doi.org/ 10.2790/125847.

[34] P. Cheali, A. Vivion, K. Gernacy, G. Sin, in: V. Krist, Gernaey, K. Jakob, R.G. Huusom (Eds.), 25th european symposium on computer-aided process engineering, Elsevier, Copenhagen, 2015, p. 2600.

[35] F. Bauer, L. Coenen, T. Hansen, K. Mccormick, Y. Voytenko Palgan, Technologica innovation systems for biorefineries - a review of the literature, Biofuels Bioprod Biorefining 11 (2017) 534-548, https://doi.org/10.1002/bbb.1767.

[36] A. Mittal, R. Katahira, B.S. Donohoe, S. Pattathil, S. Kandemkavil, M.L. Reed, et al., Ammonia pretreatment of corn stover enables facile lignin extraction, ACS Sustain Chem Eng 5 (2017) 2544-2561, https://doi.org/10.1021/acssuschemeng. $6 \mathrm{~b} 02892$

[37] R. Rinaldi, R. Jastrzebski, M.T. Clough, J. Ralph, M. Kennema, P.C.A. Bruijnincx, et al., Paving the way for lignin valorisation: recent advances in bioengineering, biorefining and catalysis, Angew Chemie Int Ed (2016)8164-8215, https://doi. org/10.1002/anie.201510351.

[38] F.R. Amin, H. Khalid, H. Zhang, S.U. Rahman, R. Zhang, G. Liu, et al., Pretreatment methods of lignocellulosic biomass for anaerobic digestion, AMB Express (2017) 7, https://doi.org/10.1186/s13568-017-0375-4.

[39] Z. Fang, R.L. Smith, X. Qi, Production of platform chemicals from sustainable resources, Springer, 2017.

[40] P.F.H. Harmsen, W.J.J. Huijgen, L.M. Bermúdez López, R.R.C. Bakker, Literature review of physical and chemical pretreatment processes for lignocellulosic biomass, BioSynergy (2010).

[41] R. Ravindran, A.K. Jaiswal, A comprehensive review on pre-treatment strategy for lignocellulosic food industry waste: challenges and opportunities pre-treatment enzymatic hydrolysis inhibitor formation reducing sugar formation lignocellulose, Bioresour Technol J 199 (2016) 92-102, https://doi.org/10.1016/j.biortech. 2015.07.106.

[42] E. Shirkavand, S. Baroutian, D.J. Gapes, B.R. Young, Combination of fungal and physicochemical processes for lignocellulosic biomass pretreatment - a review, Renew Sustain Energy Rev 54 (2016) 217-234, https://doi.org/10.1016/j.rser. 2015.10.003.

[43] S.S. Hassan, G.A. Williams, A.K. Jaiswal, Emerging technologies for the pretreatment of lignocellulosic biomass, Bioresour Technol J 262 (2018) 310-318, https: //doi.org/10.1016/j.biortech.2018.04.099.

[44] L.J. Jönsson, C. Martín, Pretreatment of lignocellulose: formation of inhibitory by-products and strategies for minimizing their effects, Bioresour Technol 199 (2016) 103-112, https://doi.org/10.1016/J.BIORTECH.2015.10.009.

[45] A.K. Kumar, S. Sharma, Recent updates on different methods of pretreatment of lignocellulosic feedstocks: a review Background, Bioresour Bioprocess (2017) 4, https://doi.org/10.1186/s40643-017-0137-9.

[46] X. Meng, A.J. Ragauskas, Mini-review recent adv petrochem sci pseudo-lignin formation during dilute acid pretreatment for cellulosic ethanol, Recent Adv Petrochem Sci (2017) 1

[47] R. Alrefai, K. Benyounis, J. Stokes, Integration approach of anaerobic digestion and fermentation process towards producing biogas and bioethanol with zero waste: technical, J Fundam Renew Energy Appl (2017) 7, https://doi.org/10. 4172/2090-4541.1000243.

[48] A. Sanz, A. Susmozas, J. Peters, J. Dufour, Biorefinery modeling and optimization, in: M. Rabaçal, A. Ferreira, C. Silva, M. Costa (Eds.), Biorefineries target. energy, high value Prod. waste valoris, Springer, 2017, p. 294.

[49] M. Coma, E. Martinez-Hernandez, F. Abeln, S. Raikova, J. Donnelly, T.C. Arnot, et al., Organic waste as a sustainable feedstock for platform chemicals, Faraday Discuss 202 (2017) 175-195, https://doi.org/10.1039/C7FD00070G.

[50] DOE, Biochemical conversion: using hydrolysis, fermentation, and catalysis to make fuels and chemicals, U.S. Department of Energy, 2013.

[51] E. Peduzzi, G. Boissonnet, G. Haarlemmer, F. Maréchal, Thermo-economic analysis and multi-objective optimisation of lignocellulosic biomass conversion to Fischer-Tropsch fuels, Sustain Energy Fuels 2 (2018) 1069-1084, https://doi.org/ 10.1039/C7SE00468K

[52] P. Tanger, J.L. Field, C.E. Jahn, M.W. Defoort, J.E. Leach, S.P. Hazen, et al., Biomass for thermochemical conversion: targets and challenges, Front Plant Sci (2013) 4, https://doi.org/10.3389/fpls.2013.00218.

[53] Y. Shen, L. Jarboe, R. Brown, Z. Wen, A thermochemical-biochemical hybrid processing of lignocellulosic biomass for producing fuels and chemicals, Biotechnol Adv 33 (2015) 1799-1813, https://doi.org/10.1016/J.BIOTECHADV.2015.10. 006

[54] C.M. Galanakis, Sustainable recovery and reutilization of cereal processing by-products, Woodhead Publishing, 2018.

[55] E. Jong, A. Higson, P. Walsh, W. Maria, Bio-based chemicals: value added products from biorefineries, IEA Bioenergy (2010).

[56] Government Queensland. Queensland Biofutures 10-Year Roadmap and Action Plan. Queensland; 2016

[57] Rancourt Y, Neumeyer C, Zou N. Reports on Special Business Projects: Result from the 2015 Bioproducts Production and Development Survey. Statistics Canada; 2017.

[58] Jungmeier G, Hingsamer M, van Ree R. Biofuel-driven Biorefineries: A Selection of the Most Promising Biorefinery Concepts to Produce Large Volumes of Road Transportation Biofuels by 2025; 2013.

[59] ePure, Roadmap to 2030: the role of ethanol in decarbonising Europe's road transport, The European renewable ethanol association, 2016 
[60] N. Urbancic, N. Renshaw, G. Archer, F. Cuenot, M. Fergusson, L. Buffet, et al., Diesel - the true dirty story, Eur Feder Transp Environ (2017).

[61] N. Hooftman, L. Oliveira, M. Messagie, T. Coosemans, J. Van Mierlo, Environmental analysis of petrol, diesel and electric passenger cars in a belgian urban setting, Energies 9 (2) (2016) 84, https://doi.org/10.3390/en9020084.

[62] S. Díaz, J. Miller, P. Mock, R. Minjares, S. Anenberg, D. Meszler, Shifting gears: the effects of a future decline in diesel market share on tailpipe CO2 and NOX emissions in Europe, The International Council on Clean Transportation, 2017.

[63] M. Angelovi, Z. Tká, M. Angelovi, Particulate emissions and biodiesel: a review, Anim Sci Biotechnol 46 (2013) 192-198.

[64] Simbolotti G. Production of liquid biofuels. IRENA; 2013.

[65] Statista. Ethanol fuel production in top countries; 2017. 〈https://www.statista. com/statistics/281606/ethanol-production-in-selected-countries/ $>$ [Accessed 10 May 2018].

[66] Statista. Global biodiesel production by country; 2016. 〈https://www.statista. com/statistics/271472/biodiesel-production-in-selected-countries/ $>$ [Accessed 10 May 2018].

[67] M.K.G. Babu, K.A. Subramanian, Alternative transportation fuels: utilisation in combustion engines, CRC Press, Taylor \& Francis, 2013.

[68] UFOP, UFOP report on global market supply 2017/2018, Union for the Promotion of Oil and Protein Plants, 2017.

[69] M. Tabatabaei, K. Karimi, I.S. Horváth, R. Kumar, Recent trends in biodiesel production, Biofuel Res J 7 (2015) 258-267, https://doi.org/10.18331/BRJ2015.2.3 4.

[70] Hirschnitz-Garbers M, Gosens J. Producing bio-ethanol from residues and wastes: a technology with enormous potential in need of further research and development; 2015.

[71] CBB. EU Handbook Biogas Markets. Cross Border Bioenergy; 2012.

[72] Flach B, Lieberz S, Rossetti A, Phillips S. EU Biofuels Annual 2017. USDA foregin agricultural service; 2017.

[73] EBA, Annual statistical report of the european biogas association, European Biogas Association, 2017.

[74] E. Tsagaraki, E. Karachaliou, I. Delioglanis, E. Kouzi, D2.1 bio-based products and applications potential, Bioways (2017).

[75] Nattrass L, Biggs C, Bauen A, Parisi C, Rodríguez-Cerezo E, Gómez-Barbero M. The EU bio-based industry: Results from a survey; 2016. 〈http://dx.doi.org/10. $2791 / 806858>$.

[76] M.E. Vallejos, M.C. Area, Xylitol as bioproduct from the agro and forest biorefinery. food bioconversion, Elsevier, 2017411-432, https://doi.org/10.1016/ B978-0-12-811413-1.00012-7.

[77] M.H. Jazini, E. Fereydouni, K. Karimi, Microbial xanthan gum production from alkali-pretreated rice straw, RSC Adv 7 (2017) 3507-3514, https://doi.org/10. 1039/C6RA26185J.

[78] BIC, Thebio-based industries vision: accelerating innovation and market uptake of bio-based products, Biobased Industries Consortium, 2012

[79] M.J. Biddy, C. Scarlata, C. Kinchin, Chemicals from biomass: a market assessmen of bioproducts with near-term potential, The National Renewable Energy Laboratory (NREL), 2016.

[80] H. Kawaguchi, T. Hasunuma, C. Ogino, A. Kondo, C. Wittmann, R. Gonzalez, Bioprocessing of bio-based chemicals produced from lignocellulosic feedstocks, Curr Opin Biotechnol 42 (2016) 30-39, https://doi.org/10.1016/j.copbio.2016.02. 031

[81] A. Kumar, A. Gautam, D. Dutt, Biotechnological transformation of lignocellulosic biomass in to industrial products: an overview, Adv Biosci Biotechnol 7 (2016) 149-168, https://doi.org/10.4236/abb.2016.73014.

[82] R. Ravindran, A. Jaiswal, Microbial enzyme production using lignocellulosic food industry wastes as feedstock: a review, Bioengineering 3 (2016) 30, https://doi. org/10.3390/bioengineering 3040030 .

[83] S2biom, Market analysis for biobased products, S2biom, 2016.

[84] M. Carus, F. Aeschelmann Bio-based building blocks and polymers: global capacities and trends 2016-2021, Huerth (2017).
[85] PlasticsEurope. Plastics - the Facts 2017: an analysis of European plastics production, demand and waste data. Brussels; 2017. 〈http://dx.doi.org/10.1016/j. marpolbul.2013.01.015

[86] Michael Carus, Bio-based building blocks and polymers in the world - capacities, production and applications: status quo and trends toward 2020, Huerth (2015).

[87]

[88]

[89] H. Thompson, E. Lora-Tamayo, W. Damm, J.-L. Dormoy, L. Hobbs, M. Jansz, et al., Interim Evaluation of the ECSEL Joint Undertaking (2014-2016) operating under Horizon 2020 (2017) https://doi.org/10.2759/614017.

[90] BBI JU - Projects n.d. 〈https://www.bbi-europe.eu/projects〉 [Accessed 15 August 2018].

[91] R\&amp; D roadmap for lignocellulosic biomass in Europe; 2016.

[92] Tsagaraki E, Karachaliou E, Delioglanis I, Kouzi E. D2.1 Bio-based products and applications potential; 2017

[93] N. Scarlat, J.-F. Dallemand, F. Monforti-Ferrario, V. Nita, The role of biomass and bioenergy in a future bioeconomy: policies and facts, Environ Dev 15 (2015) 3-34, https://doi.org/10.1016/J.ENVDEV.2015.03.006.

[94] L. Staffas, M. Gustavsson, K. McCormick, L. Staffas, M. Gustavsson, Strategies and policies for the bioeconomy and bio-based economy: an analysis of official national approaches, Sustainability 5 (2013) 2751-2769, https://doi.org/10.3390/ su5062751.

[95] Assessing the contribution of bioeconomy to countries' economy; 2018

[96] Bio-based economy for Europe: state of play and future potential Part 1 Report on the European Commission's Public on-line consultation n.d. 〈http://dx.doi.org/ $10.2777 / 67383\rangle$.

[97] BBP EG. Commission Expert Group on Bio-based Products- Final Report; 2017, p. 60.

[98] Pathways to sustainable industries; 2018.

[99] Policy asks for the bioeconomy strategy revision; 2017.

[100] Ros J, Olivier J, Notenboom J. Sustainability of biomass in a bio-based economy; 2012.

[101] Böttcher H, Frank S, Berien A:, Cres E, Alexopoulou E. Summary of main outcomes for policy makers; 2012.

[102] Supporting a Sustainable European Bioenergy Trade Strategy: Publishable Final Report. 2016.

[103] Hendriks K, Lambrecht E, Vandenhaute H, Welck H, Gellynck X, Nabuurs G-J. Potential of biomass sidestreams for a sustainable biobased economy; 2018.

[104] S.D. Ekşioğlu, A. Acharya, L.E. Leightley, S. Arora, Analyzing the design and man agement of biomass-to-biorefinery supply chain, Comput Ind Eng 57 (2009) 1342-1352, https://doi.org/10.1016/J.CIE.2009.07.003.

[105] B.H. Gebreslassie, Y. Yao, F. You, Multiobjective optimization of hydrocarbon biorefinery supply chain designs under uncertainty, Proc IEEE Conf Decis Control (2012) 5560-5565, https://doi.org/10.1109/CDC.2012.6426661.

[106] M.J. Bussemaker, K. Day, G. Drage, F. Cecelja, Supply chain optimisation for an ultrasound-organosolv lignocellulosic biorefinery: impact of technology choices, Waste Biomass Valoriz 8 (2017) 2247-2261, https://doi.org/10.1007/ s12649-017-0043-6

[107] E. Nagy, I. Hegedüs, Second generation biofuels and biorefinery concepts focusing on central europe, Chem Eng Trans 45 (2015) 1765-1770, https://doi.org/10. 3303/CET1545295.

[108] K. Menrad, A. Klein, S. Kurka, Interest of industrial actors in biorefinery concepts in Europe, Biofuels Bioprod Biorefining 3 (2009) 384-394, https://doi.org/10. 1002/bbb.144.

[109] A. Sanna, Advanced biofuels from thermochemical processing of sustainable biomass in Europe, BioEnergy Res 7 (2014) 36-47, https://doi.org/10.1007/ s12155-013-9378-4.

[110] Dammer L, Carus M, Iffland K, Piotrowski S, Sarmento L, Chinthapalli R, et al. Current situation and trends of the bio-based industries in Europe. Curr Situat Trends Bio-Based Ind Eur with a Focus Bio-Based Mater; 2017, p. 213. 